\title{
Knowledge, attitudes and practices towards COVID-19 among Pakistani residents: information access and low literacy vulnerabilities
}

Zafar Fatmi, ${ }^{1}$ Shafaq Mahmood, ${ }^{1}$ Waqas Hameed, ${ }^{1}$ Ibtisam Qazi, ${ }^{1}$ Muhammad Siddiqui, ${ }^{1}$ Anny Dhanwani ${ }^{1}$ and Sameen Siddiqi ${ }^{1}$

${ }^{1}$ Department of Community Health Sciences, The Aga Khan University, Karachi, Pakistan. (Correspondence to: Shafaq Mahmood: shafaq.mahmood@ aku.edu).

\begin{abstract}
Background: Coronavirus disease (COVID-19) has accentuated the need for speedy access to information. Digital divide and socio-demographic disparity create an information hiatus and therefore unhealthy practices with regard to dealing with COVID-19, particularly in low- and middle-income countries.

Aims: We assessed knowledge, attitudes, practices and their determinants regarding COVID-19 in Pakistan during March-April 2020.

Methods: 905 adults $\geq 18$ years (males and females) participated: 403 from a web-based survey; 365 from an urban survey; and 137 from a rural survey. Frequency of adequate knowledge, attitudes and practices for the three populations was determined based on available global guidelines. Multivariable logistic regression analysis determined factors of adequacy of knowledge, attitudes, practices, and association of knowledge with attitudes and practices.

Results: Mean age of the participants was 33.5 (+ SD 11.1) years, 51\% were females. More females and young adults (18-30 years) participated in the web-based survey. The urban survey and web-based survey participants had significantly higher adequate knowledge (2-7 times) and practices (4-5 times) towards COVID-19. Adequate knowledge had a significant influence on healthy attitudes and practices for COVID-19, after adjustment for covariates. Overall, two-thirds of the population had high levels of fear about COVID-19, which was highest among the rural survey population.

Conclusion: Substantial gaps exist in adequate knowledge, attitudes and practices, particularly among rural populations, and underscores the variation in access to information according to level of education and access to the internet. Thus, a comprehensive, contextually congruent awareness raising strategy is urgently needed to confront COVID-19 among these populations.
\end{abstract}

Keywords: knowledge, attitude, practice, COVID-19, Pakistan

Citation: Fatmi Z; Mahmood S; Hameed W; Qazi I; Siddiqui MM; Dhanwani A; et al. Knowledge, attitudes and practices towards COVID-19 among Pakistani residents: information access and low literacy vulnerabilities. East Mediterr Health J. 2020;26(12):1446-1455. https://doi.org/10.26719/emhj.20.133

Received: 15/06/20; accepted: 12/10/20

Copyright (c) World Health Organization (WHO) 2020. Open Access. Some rights reserved. This work is available under the CC BY-NC-SA 3.0 IGO license (https://creativecommons.org/licenses/by-nc-sa/3.o/igo).

\section{Introduction}

The coronavirus disease (COVID-19) outbreak has caused over 7.15 million infections and more than 408 ooo deaths during 31 December 2019-11 June 2020 (1). The pandemic has stretched health systems globally, affecting high- and low-income countries. An almost global consensus confirms that tackling COVID-19 would require a multisectoral response, well beyond health systems, that requires engagement not only from other sectors but also from communities and the public at large (2). While much has been published on the nature and extent of the health system response $(3,4)$, there is relatively limited understanding of how communities perceive COVID-19, especially in low- and middle-income countries (LMICs) (5).

Simple measures related to personal protection such as wearing masks or hand washing, or those that involve testing and tracing contacts, and more complex interventions such as imposition of lockdowns, prohibitions on public gatherings and closures of public places, can only be successful if the population has adequate knowledge and appropriate attitudes that would ensure their effective implementation (6). This becomes an even bigger challenge in populations where literacy levels are not universal and traditional, cultural and religious practices can impede the implementation of such interventions. The only hope for resourceconstrained LMICs lies in empowering communities so that they can take both short and long-term protective measures (7).

Pakistan currently has over 120000 confirmed cases and 2356 deaths (11 June 2020) with $92 \%$ of cases being due to community transmission (8). It also suffers from a weak health system, a digital divide and low literacy levels, thus highlighting the need for a comprehensive communication strategy to protect the population against COVID-19. In light of the above, the department of Community Health Sciences at The Aga Khan University conducted a survey to determine the level of knowledge, attitudes and practices (KAP) and their determinants towards COVID-19 among three sub-populations in 
Pakistan: web-users, urban and rural communities. In addition, we also determined the level of fear among the study populations regarding COVID-19 and their satisfaction with government efforts to mitigate the effects of the pandemic.

\section{Methods}

\section{Design, setting and sampling strategy}

A cross-sectional survey was conducted among three separate sections of the sample adult population $(>18$ years male and female) in Pakistan. The primary reason for selecting three diverse groups was to access equal representation of both urban and rural communities, as well as those who have better access to internet and social media. For the first group (web-based survey [WBS]), the data were collected online through a self-administered questionnaire developed using Google Forms. The link for the questionnaire was disseminated throughout $\mathrm{Pa}$ kistan via email, WhatsApp and Facebook groups (16-31 March 2020). The second group (rural survey [RS]), was an interviewer-based household survey (19-22nd March 2020); however, the survey was interrupted due to the lockdown by the government in Thatta district. The third survey (urban survey [US]) was conducted by telephone (list was available from previous study) in Karachi. For the US group, a total of 30 clusters were randomly selected using sampling frame of the Pakistan Bureau of Statistics. From each cluster approximately 15 interviews were conducted. Similarly, for the RS group the villages (as clusters) $(n=10)$ were randomly selected based on available sampling frame of the Rural Health Programme (RHP) at the Aga Khan University. The RHP is an implementation science approach to improving population health, which was established in collaboration with the Health Department of Thatta district from January 2018.

\section{Sample size}

The survey was designed to determine the proportion of adequate KAP. 'Adequacy' refers to being aware of, having a favourable attitude towards, and practicing key set standards (Table 1). In the absence of any local evidence, we used $50 \%$ as the anticipated proportion of adequate KAP with $95 \%$ confidence level (CI) and a $7 \%$ margin of error; a sample of 196 was estimated for each strata (total for three strata was 588). The sample was inflated by 1.25 for design effect (735) and 10\% for non-response, creating a total of 809 participants, i.e. 269.7 or 270 per survey strata. Total number of respondents was 905; however, the number was less for RS group due to a local lockdown (WBS $=403$, US $=365$ and $\mathrm{RS}=137$ ).

\section{Data collection tool and measures}

The study was approved by the Ethics Review Committee of Aga Khan University. All interview-based data (US and RS) were collected electronically using Epicollect5, which has validation checks to minimize data errors. Data collectors with prior experience were hired and trained to conduct face-to-face and telephone interviews. Moreover, a qualified biostatistician performed data analysis for the study. The socio-demographic variables included age, sex, place of residence (Karachi vs. other cities), education and employment status. Furthermore, we also inquired about perceived satisfaction (on Likert scale of 1 to 5) regarding government efforts and fear among participants regarding COVID-19 on a scale of 1 to 10 (1 being 'no fear' to 10 'extreme fear and anxiety').

The knowledge questionnaire was developed in accordance with international guidelines for the prevention of COVID-19 $(9,10)$. The questionnaire was pretested at Aga Khan University among the interviewers. It comprised of questions on COVID-19 signs and symptoms, modes of transmission, high-risk populations, preventive measures, myths and misconceptions, incubation and quarantine period, and health-seeking behaviours (Supplementary Table 1 online). Based on key knowledge parameters (Table 1), participants were categorized as having 'adequate' or 'inadequate' knowledge.

Attitudes and practices towards COVID-19 transmission and its prevention were each assessed using 7 items, recorded on a 5-point and 3-point Likert scale, respectively (Supplementary Table 2 and 3 online). The respondents were considered to have a positive attitude if they responded correctly to all 7 attitude items. Similarly, the participants who 'always' ensured hand hygiene, cough etiquette and social distancing were considered to have 'adequate' practice against COVID-19.

\begin{tabular}{ll}
$\begin{array}{l}\text { Table } 1 \text { Criteria for adequate knowledge } \\
\text { Knowledge parameter }\end{array}$ & \multicolumn{1}{c}{ Criteria for adequate knowledge } \\
Signs and symptoms & $\begin{array}{l}\text { Mentioned } 4 \text { key signs and symptoms out of } 10 \text { listed i.e. fever, cough, joint/muscle pain, and } \\
\text { breathing difficulty. } \\
\text { Mentioned coughing/sneezing, hand shaking, and sharing personal belongings with } \\
\text { infected person as potential modes of transmission. } \\
\text { Identified smokers, asthmatics, diabetics, the elderly and people in crowed places as high } \\
\text { risk individuals for acquiring COVID-19 disease. } \\
\text { At-risk population }\end{array}$ \\
Preventive measures & $\begin{array}{l}\text { Mentioned hand hygiene, cough etiquettes and social distancing as essential practices to } \\
\text { Knew the exact quarantine duration, i.e. } 14 \text { days. }\end{array}$ \\
Quarantine guidelines & $\begin{array}{l}\text { Identified antibiotics, pneumonia vaccine and herbal remedies as incorrect therapies for } \\
\text { COVID-19. }\end{array}$ \\
\hline Treatment practices & \\
\hline
\end{tabular}




\begin{tabular}{|c|c|c|c|c|c|c|}
\hline \multirow[t]{2}{*}{ Characteristics } & \multicolumn{2}{|c|}{$\begin{array}{c}\text { Urban population } \\
\text { (US) } \\
N=365\end{array}$} & \multicolumn{2}{|c|}{$\begin{array}{c}\text { Rural population } \\
\text { (RS) } \\
N=137\end{array}$} & \multicolumn{2}{|c|}{$\begin{array}{c}\text { Web-based } \\
\text { population (WBS) } \\
N=403\end{array}$} \\
\hline & n & $\%$ & $\mathbf{N}$ & $\%$ & $n$ & $\%$ \\
\hline \multicolumn{7}{|l|}{$\operatorname{Sex}^{*}$} \\
\hline Male & 296 & 81.1 & 55 & 40.1 & 90 & 22.5 \\
\hline Female & 69 & 18.9 & 82 & 59.9 & 310 & 77.5 \\
\hline \multicolumn{7}{|l|}{ Age (years) } \\
\hline $18-30$ & 108 & 29.6 & 60 & 43.8 & 277 & 68.7 \\
\hline$>30$ & 257 & 70.4 & 77 & 56.2 & 126 & 31.3 \\
\hline Mean $( \pm S D)$ & \multicolumn{2}{|c|}{$39.0(+12)$} & \multicolumn{2}{|c|}{$34.0(+11)$} & \multicolumn{2}{|c|}{$28.0(+8)$} \\
\hline \multicolumn{7}{|l|}{ Education } \\
\hline No literacy & 27 & 7.4 & 110 & 80.3 & 0 & 0.0 \\
\hline Undergraduate or below & 272 & 74.5 & 23 & 16.8 & 67 & 16.6 \\
\hline Graduate or above & 66 & 18.1 & 4 & 2.9 & 336 & 83.4 \\
\hline \multicolumn{7}{|l|}{ Employment status } \\
\hline Employed & 181 & 49.6 & 52 & 38.0 & 178 & 44.2 \\
\hline Student & 11 & 3.0 & 3 & 2.2 & 154 & 38.2 \\
\hline Housewife & 52 & 14.2 & 80 & 58.4 & 47 & 11.7 \\
\hline Unemployed/retired & 121 & 33.2 & 2 & 1.5 & 24 & 6.0 \\
\hline Total & 365 & 100.0 & 137 & 100.0 & 403 & 100.0 \\
\hline
\end{tabular}

* 3 participants from WBS group did not mention their sex

\section{Statistical analysis}

Data analysis was performed using Statistical Package for Social Sciences (SPSS) version 21.0. Descriptive statistics for the three surveys (WBS, US and RS) and overall statistics were generated. Multivariable logistic regression was conducted to determine the adjusted factors associated with adequate knowledge, attitudes and practices, respectively. Furthermore, association of adequate knowledge with attitudes and practices were also determined after adjusting for socio-demographic covariates.

\section{Results}

\section{Sociodemographic characteristics}

Sociodemographic characteristics for all three survey groups and the total sample are summarized in Table 2. A total of 905 participants were included in the survey with a mean age of $33.51 \pm$ SD 11.1 years, $51.1 \%$ were females. More females participated in the RS (60\%) and WBS (78\%) group surveys compared to the telephone survey in the US group (19\%). The literacy rate was higher in the WBS (100\%) and the US groups (70\%) compared to the RS group (20\%).

Almost all participants had heard about COVID-19. Overall, $12 \%$ respondents gave a history of contact with a foreign traveler during the past 14 days. The main sources of information for WBS and US groups were online and social media ( $82 \%$ and $79 \%$ respectively). The RS group, however, received $32 \%$ of its information from family/friends/colleagues and only 18\% through social media (Supplementary Figure 1 online). The frequency of correct responses for each KAP item/question for the three survey groups are provided in supplementary Tables 1-3 (online). Figure 1 shows the overall adequacy of KAP among survey participants according to the criteria mentioned in Table 1.

\section{Knowledge regarding COVID-19}

A majority (76-92\%) were aware of the common signs and symptoms of COVID-19 including fever, cough and shortness of breath; however, joint/muscle pain was identified by only $40 \%$. Furthermore, only $12.7 \%$ were aware that it can present without any symptoms (Supplementary Table 1 online). US group participants ( $\mathrm{AOR}=4.1$, compared to RS group) and participants holding a Bachelor's degree or above ( $\mathrm{AOR}=3.5$, compared with no literacy) had a higher odds of adequate knowledge about the signs and symptoms (Table 3).

Shaking hands, droplet infection and sharing personal belongings were considered as the three most common modes of transmission by $74-96 \%$ of the US and WBS group participants. Knowledge about transmission 


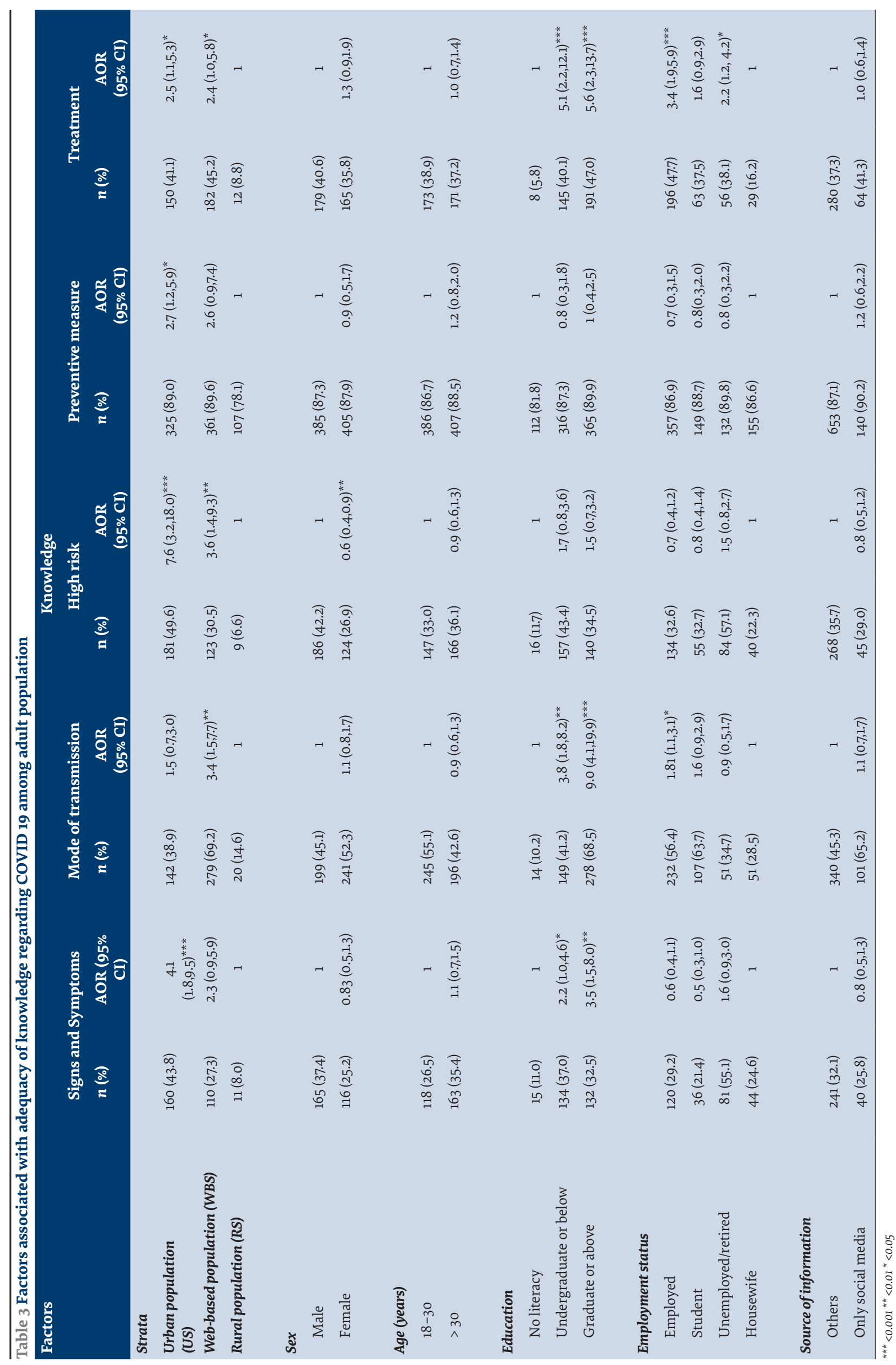




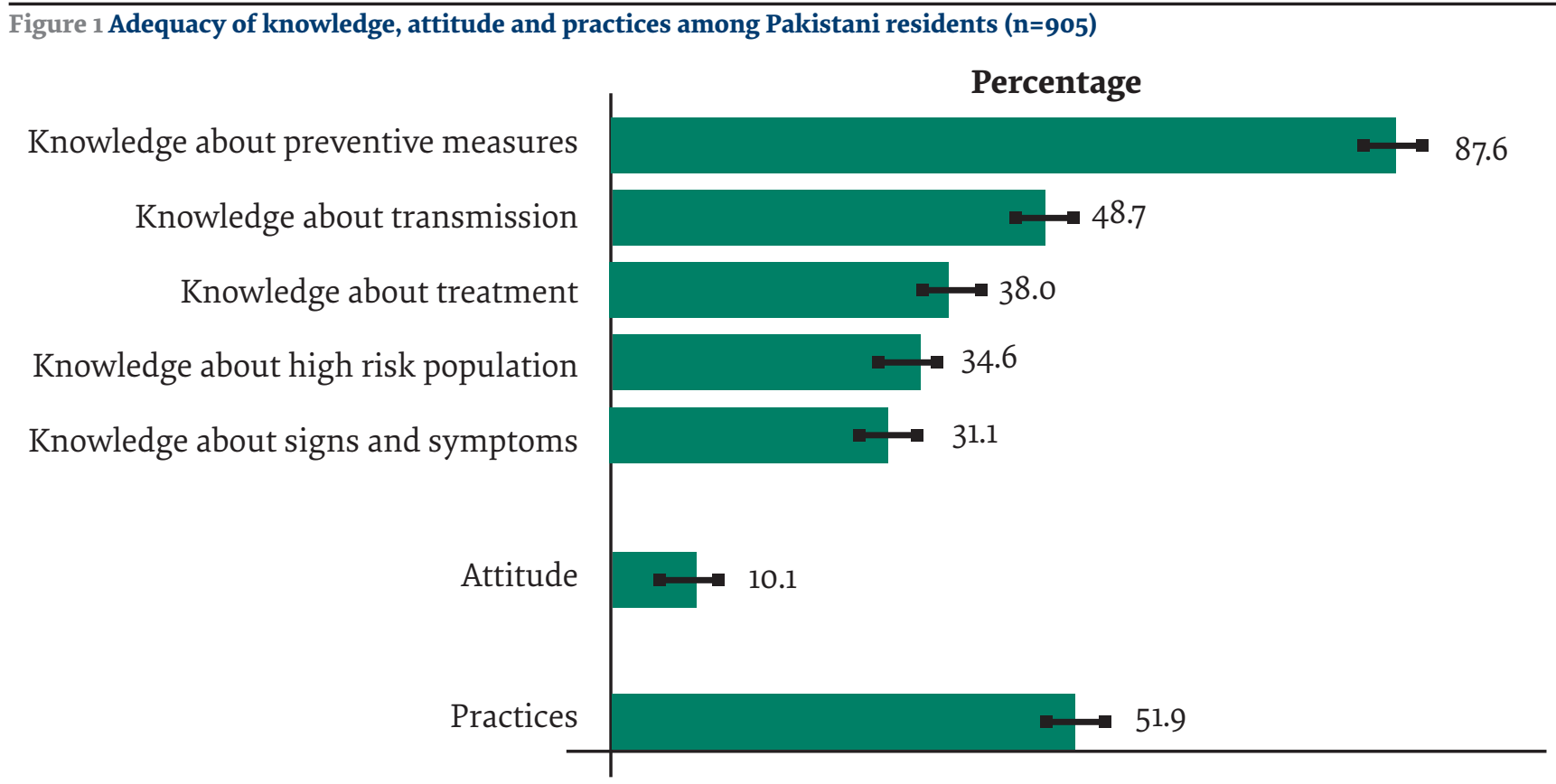

Black bar represents $95 \%$ confidence level

was comparatively lower among the RS group, with $74 \%$ of the participants incorrectly considering a mosquito bite as a means of transmission for COVID-19 (Supplementary Table 1 online). Belonging to the WBS group ( $\mathrm{AOR}=3.4$, compared to RS group), having higher literacy i.e. graduate level and above $(\mathrm{AOR}=9.0$, compared no literacy), and those who were employed ( $\mathrm{AOR}=1.8$, compared with housewives) had a higher likelihood of adequate knowledge about the mode of transmission of COVID-19 (Table 3).

Older people as a high-risk group for acquiring COVID-19 infection were uniformly (90-97\%) identified by all three survey groups. However, the knowledge about other common risk factors (smokers, asthmatics, diabetics, and crowded places) was less known, especially in the RS group $(<50 \%)$ (Supplementary Table 1 online). Adequate knowledge about risk factors was significantly higher among the US (AOR=7.6) and WBS (AOR=3.6) groups compared to the RS group, while females had less awareness about high risks $(\mathrm{AOR}=0.6)$ compared to males (Table 3a).

Uniformly, all three survey groups had knowledge about hand hygiene (97\%), cough etiquette (94\%), social distancing (93\%) and wearing a face mask in crowded places $(68 \%)$. However, about half of the respondents incorrectly believed that vaccination can protect against COVID-19 (Supplementary Table 1 online). The adequacy of knowledge about preventive measures were significantly higher among US participants $(A O R=2.7$, compared to RS) (Table 3a).

A higher proportion of participants (71-83\%) in the RS group were supportive of incorrect treatment practices such as herbal remedies, pneumonia vaccine and antibiotics/medicines against COVID-19. Incorrect treatment measures were also supported commonly
$(60-82 \%)$ by WBS and US groups (Supplementary Table 1 online). The adequacy of knowledge about correct treatment measures was significantly higher among the US and WBS groups ( $\mathrm{AOR}=2.4-2.5$, compared to RS group), graduate level and above $(\mathrm{AOR}=5.6$, compared to no literacy), and employed $(\mathrm{AOR}=3.4$, compared to housewives) (Table 3a).

\section{Attitude towards COVID-19 prevention}

As compared to US group (52\%), a higher percentage (94\%98\%) of RS and WBS population agreed that a handkerchief must be used by a person to cover his nose/mouth while coughing/sneezing. Similarly, most people believed that COVID-19 could spread from one to others (80.2\%) hence they must restrict their routine mobility (90\%). More than $95 \%$ of the survey respondents agreed that it is important to report a suspected COVID-19 case to health authorities and the government should restrict travel from and to areas of high transmission. Nearly 100\% of the population in the RS group considered themselves prepared for the COVID-19 outbreak, however, 33\% people in the WBS group gave a contrasting response (Supplementary Table 2 online). Computing the overall attitude showed an unfavourable attitude prevalent in more than $90 \%$ of the survey population (Figure 2). Educated participants (AOR=4.9-7.3, compared to no literacy) had significantly better attitudes. However, the WBS $(A O R=0.6)$ and US $(\mathrm{AOR}=0.2)$ group participants had poorer attitudes than the RS group (Table 4).

\section{Practices regarding COVID-19 prevention}

Washing and sanitizing hands was fairly common in the WBS (88.3\%) and US (91.2\%) groups and less common (54.7\%) in the RS group. Most participants (approximately $65 \%$ ) ensured hand hygiene took place more commonly after touching personal belongings or shaking hands with 


\begin{tabular}{|c|c|c|c|c|}
\hline \multirow[t]{2}{*}{ Factors } & \multicolumn{2}{|c|}{ Attitude } & \multicolumn{2}{|c|}{ Practices } \\
\hline & $n(\%)$ & $\operatorname{AOR}(95 \% \mathrm{CI})$ & n (\%) & $\operatorname{AOR}(95 \% \mathrm{CI})$ \\
\hline \multicolumn{5}{|l|}{ Strata } \\
\hline Urban population (US) & $18(4.9)$ & $0.2(0.1,0.5)^{* * *}$ & $221(60.5)$ & $5.2(2.6,10.5)^{* * *}$ \\
\hline Web-based population (WBS) & $59(14.6)$ & $0.6(0.2,1.7)$ & $224(55.6)$ & $4 \cdot 1(1.8,9 \cdot 2)^{* * *}$ \\
\hline Rural population (RS) & $14(10.2)$ & 1 & $25(18.2)$ & 1 \\
\hline \multicolumn{5}{|l|}{ Sex } \\
\hline Male & $37(8.4)$ & 1 & $224(50.8)$ & 1 \\
\hline Female & $53(11.5)$ & $1.4(0.8,2.6)$ & $243(52.7)$ & $1.46(1.0,2.2)$ \\
\hline \multicolumn{5}{|l|}{ Age (years) } \\
\hline $18-30$ & $60(13.5)$ & 1 & $225(50.6)$ & 1 \\
\hline$>30$ & $31(6.7)$ & $0.6(0.3,0.9)^{* *}$ & $245(53.3)$ & $1.0(0.7,1.3)$ \\
\hline \multicolumn{5}{|l|}{ Education } \\
\hline No literacy & $7(5.1)$ & 1 & $32(23.4)$ & 1 \\
\hline Undergraduate or below & $30(8.3)$ & $4.9(1.5,16.2)^{* *}$ & $201(55.5)$ & $1.9(1.0,3.6)$ \\
\hline Graduate or above & $54(13.3)$ & $7.3(2.1,25.4)^{* *}$ & $237(58.4)$ & $2.0(1.0,4.1)^{*}$ \\
\hline \multicolumn{5}{|l|}{ Employment status } \\
\hline Employed & $49(11.9)$ & $1.6(0.7,3.7)$ & $212(51.6)$ & $0.8(0.5,1.3)$ \\
\hline Student & $22(13.1)$ & $1.3(0.5,3.2)$ & $77(45.8)$ & $0.4(0.2,0.8)^{* *}$ \\
\hline Unemployed/retired & $8(5.4)$ & $1.0(0.3,3.1)$ & 97 (66.o) & $1.3(0.7,2.5)$ \\
\hline Housewife & $12(6.7)$ & 1 & $84(46.9)$ & 1 \\
\hline \multicolumn{5}{|l|}{ Source of information } \\
\hline Others & $72(9.6)$ & 1 & $397(52.9)$ & 1 \\
\hline Only social media & $19(12.3)$ & $0.8(0.4-1.4)$ & $73(47.1)$ & $0.6(0.4-0.8)^{* *}$ \\
\hline
\end{tabular}

${ }^{* * *}<0.001{ }^{* *}<0.01{ }^{*}<0.05$

people suffering from a cough or cold. A lesser proportion (43.6\%) were washing hands after touching door handles. Among the RS group, 60\% participants did not practice cough etiquette and only $17.5 \%$ reported disposing of used tissues (Supplementary Table 3 online). The adequacy of key practices against COVID-19 prevention were significantly better in the US and WBS groups ( $\mathrm{AOR}=5.2,4.1$, compared to $R S)$, graduates and above $(A O R=2.0)$ while students had less likelihood of following adequate practices (AOR=0.4, compared to housewives) (Table 4).

\section{Fear score and satisfaction of survey participants with government efforts}

The mean anxiety (fear) score of the participants was measured on a scale of 1 to 10 and equaled 6.4 (Supplementary Figure 2 online). Nearly $52.7 \%$ of the participants were not satisfied with the level of preparedness by the government in their community against the COVID-19 outbreak.

\section{Association of knowledge with attitude and practice}

Adequate knowledge was significantly associated with improved attitudes (AOR=1.5-2.0) (Table 3a) and healthy practices ( $\mathrm{AOR}=1.5-2.0$ ) (Table 3a), after adjustment for covariates (Supplementary Table 4 online).

\section{Discussion}

This is among the first studies to determine the KAP regarding COVID-19 from a LMIC (Pakistan) in three population subgroups. It provides a comparison between those who are literate and have ready access to information, and those who are less literate and less likely to have access to reliable information - presently the majority in Pakistan. First, not surprisingly our study noted that those who responded through WBS were more literate and lived in a large city (Karachi), had a higher level of knowledge, favourable attitudes, and practices. The rural population on the other hand had the least information about COVID-19. Second, the study identified substantial gaps and variations in knowledge about signs and symptoms, risk factors, modes of transmission and treatment options for COVID-19. Third, the study substantiates that having adequate knowledge correlates well with the likelihood of appropriate attitudes and healthy practices and underscores the need for urgent intervention for improving the level of knowledge. Lastly, the study also highlights that the key prevention messages currently circulating through various media/channels do have an impact on improving knowledge on different aspects of COVID-19. Thus, if the messages are made comprehensive, it will make a difference and disseminate throughout the population. 
Pakistan and many LMICs are facing a substantial digital divide; $81 \%$ of the population in high-income countries compared to $41 \%$ among low- and middleincome countries have access to the internet (11). In Pakistan, internet penetration has risen to 68 million citizens (33\% population), of which $21 \%$ are males and $12 \%$ females, and the majority is urban populations (12). There is also evidence that the COVID-19 crisis has accelerated the uptake of digital solutions, tools and services, speeding up the global transition towards a digital economy, as well as exposing the wide gap between those who enjoy access to the internet and those who do not (13).

Few online KAP surveys have been conducted in Pakistan that primarily targeted the educated segment of the population, such as health-care providers and university students. Most of these studies have indicated a good knowledge about the common signs and symptoms (84-93\%) and preventive strategies related to COVID-19 (72-92\%). However, few (55\%) were aware of the correct incubation period of the disease, as evident through our study $(14,15)$. Another community-based survey showed relatively poor knowledge about the disease, where only $45.3 \%$ of the study population considered close physical contact as a risk factor for the spread of infection (16).

Similar studies conducted in Jordan $(17,18)$, Viet Nam (19), China (20) and India (21,22) also discovered better knowledge among educated people who have access to reliable information. Younger adults, males and those who were unemployed had a lower level of knowledge about COVID-19 in our study population. These trends are similar to studies conducted in China and Spain, where younger adults, males, never-married, less educated, and unemployed perceived the pandemic as less threatening, and scored lower on knowledge, personal concern and compliance with safety measures $(23,24)$.

Attitudes regarding COVID-19 need improvement when considering a third of the overall population thought the disease to be of no significance. A country's response and leadership also shape attitude. For example, Nicaragua had the poorest response to COVID-19 by refusing World Health Organization (WHO) recommended mitigation strategies at the state level. There are similarities to such responses in subpopulations in Pakistan where certain political and religious clerics are defying government orders (25). Our survey also suggests that $75 \%$ of the population in Pakistan have a high level of fear about COVID-19, especially those living in rural areas. Thus, there is an urgent need to provide psychosocial support to prevent adverse mental health conditions in Pakistan.
The government in partnership with academia, civil society and the media should launch a campaign using innovative strategies targeted at different population groups. Electronic and print media provide good access to information among populations with access to the internet. However, broadband internet penetration is only $36 \%$ and two-thirds of the population in Pakistan use non-smart phones (dumb-phones); therefore, audio messages and other community platforms are needed to reach this population (26).

\section{Limitations}

A number of limitations need to be considered. First, the WBS platform was not sent to a specified number of respondents, rather its link was uploaded on various social media platforms; hence the response rate for WBS could not be determined. However, a higher proportion of the younger and well-educated population responded to the online survey, thus it may serve as an indicator of the highest level of knowledge base among the population sub-groups in Pakistan. The response rate for telephone survey (US group) was 33\%, with most respondents being older males, whereas the response rate for the faceto-face survey (RS) reached $100 \%$. Low response rates in telephone surveys is a commonly encountered problem; response rates for telephone surveys in the United States of America have been declining consistently since 1997 (36\%) and have now bottomed out at around 9\% in 2016 (27). Furthermore, wish-bias may play a role in the response, as with all KAP studies. The survey provided valuable information on KAP and the best possible coverage of the population of Pakistan. However, it cannot be considered a representative survey for Pakistan. Lastly, the findings of this study are self-reported and dependent on the participant's ability to recall; thus, the likelihood of recall bias cannot be excluded.

\section{Conclusion}

There was a substantial gap in knowledge, attitudes and practices regarding COVID-19 among the various population groups, particularly for those residing in rural areas of Pakistan. Certain gaps in information such as the mode of transmission of disease, quarantine period and treatment options were uniformly seen across all groups irrespective of their level of literacy. Thus, a comprehensive and contextually congruent awareness-raising strategy suited to the need of urban and rural population is urgently needed in the fight against COVID-19.

Funding: None.

Competing interests: None declared. 


\section{Connaissances, attitudes et pratiques vis-à-vis de la COVID-19 dans la population totale du Pakistan : accès à l'information et vulnérabilité associée à une faible alphabétisation}

\section{Résumé}

Contexte: La maladie à coronavirus (COVID-19) a accentué la nécessité d'un accès rapide à l'information. La fracture numérique et la disparité sociodémographique créent un hiatus de l'information et conduisent ainsi à des pratiques malsaines en ce qui concerne la prise en charge de la COVID-19, en particulier dans les pays à revenu faible et intermédiaire.

Objectifs : Nous avons évalué les connaissances, les attitudes, les pratiques et leurs déterminants concernant la COVID-19 au Pakistan entre mars et avril 2020.

Méthodes : 905 adultes âgés de 18 ans et plus (hommes et femmes) ont participé : 403 dans le cadre d'une enquête en ligne, 365 au titre d'une enquête menée en milieu urbain et 137 dans une enquête en milieu rural. La fréquence des connaissances, des attitudes et des pratiques adéquates pour les trois populations a été déterminée sur la base des lignes directrices mondiales disponibles. L'analyse de régression logistique multivariable a déterminé des facteurs d'adéquation des connaissances, des attitudes, des pratiques et de l'association des connaissances avec les attitudes et les pratiques.

Résultats : L'âge moyen des participants était de 33 ans et demi (+ écart-type 11,1), 51 \% étant des femmes. Davantage de femmes et de jeunes adultes (18 à 30 ans) ont participé à l'enquête en ligne. Les participants à l'enquête menée en milieu urbain et à l'enquête en ligne avaient des connaissances et des pratiques adéquates beaucoup plus importantes en matière de COVID-19 ( ( 2 à 7 fois et 4 à 5 fois plus importantes respectivement). Le fait d'avoir des connaissances adéquates avait une influence significative sur les attitudes et les pratiques saines concernant la COVID-19, après ajustement en fonction des covariables. Globalement, les deux tiers de la population ont exprimé une grande crainte à l'égard de la COVID-19, le niveau le plus élevé se trouvant parmi la population ayant participé à l'enquête menée en milieu rural.

Conclusions : Il existe des lacunes substantielles dans les connaissances, les attitudes et les pratiques adéquates, en particulier parmi la population rurale, et il convient de souligner les variations dans l'accès à l'information selon le niveau d'éducation et l'accès à l'Internet. Il est donc urgent de mettre en place une stratégie de sensibilisation globale, adaptée au contexte, pour lutter contre la COVID-19 dans ces populations.

$$
\text { الخلاصة فاطمي، شفق مات والاتجاهات والملارسات تجاه كوفيد- } 19 \text { بين الباكستانين: الوصول وقاص حميد، ابتسام قاضي، محمد صديقي، آني ظانواني، ثمين صديقي مات وضعف الإلمام بالقراءة والكتابة }
$$

الخلفية: لقد أبرز مرض فيروس كورونا (كوفيد- 19) الحاجة إلى سرعة الخصول على المعلومات. وتحلق الفجوة الرقمية والتفاوت الاجتماعي

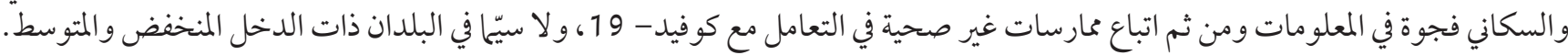
الأهداف: هدفت هذه الدراسة إلى تقييم المعلو مات و الاتجاهات و الملمارسات ومحدداتها بشأن كوفيد- 19 في باكستان من مارس/ آذار إلى أبريل/ نيسان 2020.

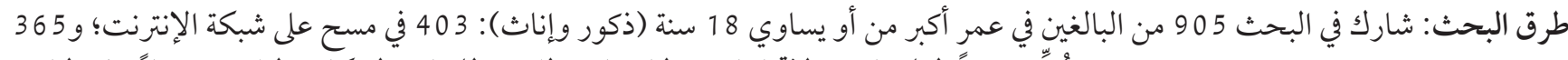

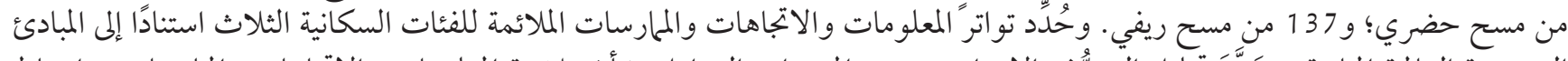

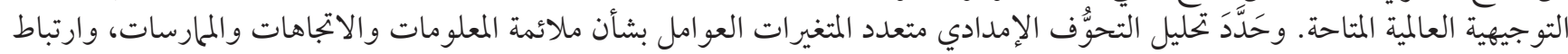
المعلو مات مع الاتجاهات والممارسات.

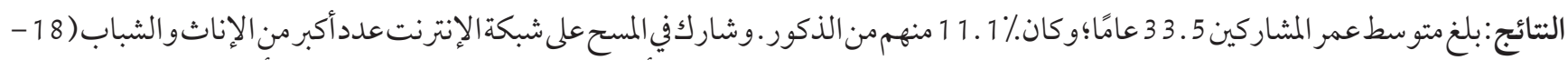

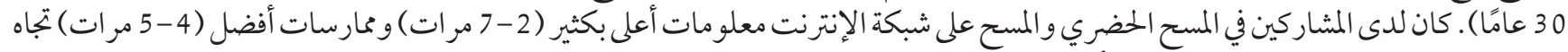

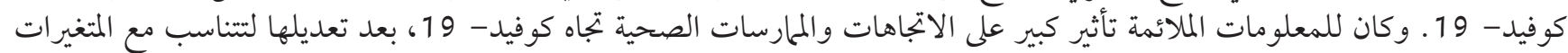

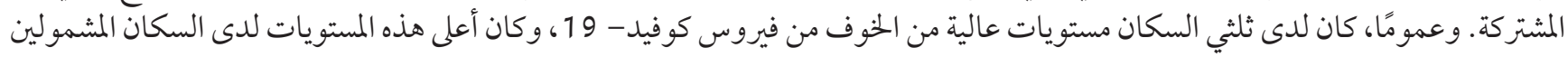
بالمستح الريفي.

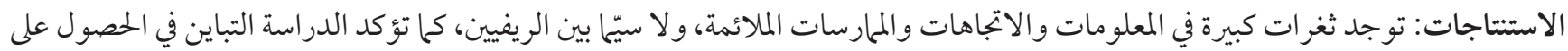

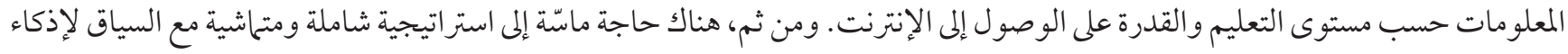
الوعي لمواجهة كوفيد- 19 بين هذه الفئات السكانية. 


\section{References}

1. Worldometer. COVID-19 Coronavirus pandemic. Reported cases and deaths by country, territory, or conveyance (https://www. worldometers.info/coronavirus/\#countries).

2. Qian X, Ren R, Wang Y, Guo Y, Fang J, Wu Z-D, et al. Fighting against the common enemy of COVID-19: a practice of building a community with a shared future for mankind. Infect Dis Poverty. 9;34(2020). https://doi.org/10.1186/s40249-020-00650-1

3. Lin X, Wang X, Peng Z, Wang R, Wang P, Li Z, et al. Current situation of the corona virus disease under active control and prevention in China, outside Hubei Province: a real-world epidemiological analysis 20 February 2020 SSRN (https://ssrn.com/ abstract=3543594 or http://dx.doi.org/10.2139/ssrn.3543594).

4. UK leads global fight to prevent second wave of coronavirus. London: UK Government; 2020 (https://www.gov.uk/government/ news/uk-leads-global-fight-to-prevent-second-wave-of-coronavirus).

5. Hopman J, Allegranzi B, Mehtar S. Managing COVID-19 in Low- and middle-income countries [published online ahead of print, 2020 Mar 16]. JAMA. 2020;10.1001/jama.2020.4169. doi:10.1001/jama.2020.4169

6. Zhong BL, Luo W, Li HM, Zhang QQ, Liu XG, Li WT, Li Y. Knowledge, attitudes, and practices towards COVID-19 among Chinese residents during the rapid rise period of the COVID-19 outbreak: A quick online cross-sectional survey. International Journal of Biological Sciences. 2020;16(10):1745-1752. doi: 10.7150/ijbs.45221.

7. Kelley M, Ferrand RA, Muraya K, Chigudu S, Molyneux S, Pai M, et al. An appeal for practical social justice in the COVID-19 global response in low-income and middle-income countries Lancet Glob Health. 2020;S2214-109X(20)30249-7. doi: 10.1016/S2214$109 \mathrm{X}(20) 30249-7$

8. Government of Pakistan. (http://covid.gov.pk/stats/pakistan, accessed 11 June, 2020].

9. World Health Organization. Frequently asked questions on novel coronavirus: update. Geneva: World Health Organization; 2020 (https://www.who.int/csr/disease/coronavirus_infections/faq_dec12/en/).

10. Centers for Disease Control and Prevention (CDC). Coronavirus (COVID-19). Atlanta, GA: CDC; 2020 (https://www.cdc.gov/coronavirus/2019-ncov/index.html).

11. Lumen learning. Cultural Anthropology. Chapter 14: Globalization. In Cultural Anthropology (https://courses.lumenlearning. com/culturalanthropology/chapter/the-global-digital-divide/, accessed 15 April 2020)

12. Dawar Y. Digital divide affecting more women than men. Daily Times, 15 April 2020 (https://dailytimes.com.pk/382517/digital-divide-affecting-more-women-than-men/, accessed 15 April 2020).

13. UNCTAD. Coronavirus reveals need to bridge the digital divide. (https://unctad.org/en/pages/newsdetails.aspx?OriginalVersionID=2322, accessed 15 April 2020).

14. Hussain I, Majeed A, Imran I, Ullah M, Hashmi F, Saeed H, Chaudhry MO, et al. Knowledge, attitude, and practices toward COVID-19 in primary healthcare providers: a cross-sectional study from three tertiary care hospitals of Peshawar, Pakistan. J Community Health. 2020;Jul 6:1-9.

15. Salman M, Mustafa ZU, Asif N, Zaidi HA, Hussain K, Shehzadi N, et al. Knowledge, attitude and preventive practices related to COVID-19: A cross-sectional study in two Pakistani university populations. Drugs Ther Perspect. 2020 May 9:1-7. doi: 10.1007/ S40267-020-00737-7.

16. Afzal MS, Khan A, Qureshi RU, Saleem S, Saqib NAM, Shabbir KMR, et al. Community-based assessment of knowledge, attitude, practices and risk factors regarding COVID-19 among Pakistani residents during a recent outbreak: a cross-sectional survey. J Community Health. 2020;Jul 13:1-11.

17. Khader Y, Al Nsour M, Al-Batayneh OB, Saadeh R, Bashier H, Alfaqih M, et al. Dentists' awareness, perception, and attitude regarding COVID-19 and infection control: cross-sectional study Among Jordanian dentists. JMIR Public Health Surveill 2020;6(2):e18798.

18. Alzoubi H, Alnawaiseh N, Al-Mnayyis A, Abu Lubada M, Aqel A, Al-Shagahin H. COVID-19 - knowledge, attitude and practice among medical and non-medical university students in Jordan. J Pure Appl Microbiol. 2020;14(1):17-24.

19. Hyynh G, Nguyen TN, Tran VK, Vo KM, Vo VT, Pham LA. Knowledge and attitude toward COVID-19 among healthcare workers at District 2 Hospital, Ho Chi Minh City. Asian Pac J Trop Med. 2020;13(6):260-265. (http://www.apjtm.org/preprintarticle. asp?id=280396; type =0, accessed 15 April 2020).

20. Shi Y, Wang J, Yang Y, Wang Z, Wang G, Hashimoto K, et al. Knowledge and attitudes of medical staff in Chinese psychiatric hospitals regarding COVID-19. Brain Behav Immun Health. 2020;Apr4:100064.

21. Gudi Sk, Undela K, Venkataraman R, Mateti UV, Chhabra M, Nyamagoud S, et al. Knowledge and beliefs towards universal safety precautions to flatten the curve during novel coronavirus disease (nCOVID-19) pandemic among general public in India: explorations from national perspective. medRxiv. 2020;Jan. (https://doi.org/10.1101/2020.03.31.20047126, accessed 15 April 2020).

22. Ranjan R, Ranjan GK. Knowledge regarding prevention of novel coronavirus (COVID-19): an electronic cross-sectional survey among selected rural community. IJTSRD 2020 April;4(3): 2456-6470 (http://www.ijtsrd.com e-ISSN: 2456 - 6470, accessed 15 April 2020).

23. Zhong BL, Luo W, Li HM, Zhang QQ, Liu XG, Li WT, et al. Knowledge, attitudes, and practices towards COVID-19 among Chinese residents during the rapid rise period of the COVID-19 outbreak: a quick online cross-sectional survey. Int J Biol Sci. 2020;16(10):1745. 
24. De La Vega R, Barquin RR, Boros S, Szabo A. Could attitudes toward COVID-19 in Spain render men more vulnerable than women? Psyarxiv Preprints (https://psyarxiv.com/dyxqn/, accessed 15 April 2020).

25. Mather TPS, Marin BG, Perez GM, Christophers B, Paiva ML, Oliva R, et al. Love in the time of COVID-19: negligence in the Nicaraguan response. Lancet Glob Health. 2020;April. doi:10.1016/s2214-109x(20)30131-5. PMID: 32272083.

26. Pakistan Telecommunication Authority (PTA). Annual Report. Islamabad; PTA; 2019 (https://www.pta.gov.pk/assets/media/ pta_ann_rep_2019_27032020.pdf).

27. Keeter S, Hatley N, Kennedy C, Lau A. What low response rates mean for telephone surveys. Washinton DC: Pew Research Center; 2017. 